\title{
Tūrisma organizācija Latvijas PSR: Latvijas republikāniskās tūrisma padomes darbība 20. gadsimta 60 . gados
}

\author{
Organisation of Tourism in Latvian SSR: Activity of \\ Republican Tourism Council of Latvia in 1960s ${ }^{1}$
}

\author{
Ilze Vaivode, Mg. hist. \\ Latvijas Universitātes Vēstures un filozofijas fakultāte \\ Aspazijas bulvāris 5, Rīga, LV-1050 \\ E-pasts: ilzevaivode@yahoo.com
}

PSRS tūrisms kḷuva par padomju identitātes un kopējās vēsturiskās atmiñas veicinātāju - tas bija îpaši svarīgi pēc Otrā pasaules kara, kad PSRS varā bija nonākušas vairākas valstis, arī Latvija. Drīz sākās tūrisma jomas atjaunošana, tika dibinātas tūrisma organizācijas, taču centieni izveidot centralizētu tūrisma organizāciju nebija sekmīgi. 60. gados notika būtiska tūrisma reorganizācija, un tādējādi šim mērḳim izdevās pietuvoties. Pētījuma mērḳis ir analizēt Latvijas tūrisma un ekskursiju pārvaldes un Latvijas republikāniskās tūrisma padomes darbību, nosakot to sasniegumus un trūkumus. Darbā skaidrota organizāciju struktūra un struktūrvienību mijiedarbība - tas veicina izpratni ne vien par tūrisma organizēšanu, bet arī par procesiem sabiedrībā Latvijas PSR.

Atslēgvārdi: tūrisms, Latvijas PSR, PSRS, Latvijas tūrisma un ekskursiju pārvalde, Latvijas republikāniskā tūrisma padome.

In the USSR, tourism played an important role in the promotion of Soviet identity and building of collective historical memory, which was necessary after the Second World War, when the USSR had occupied many countries, including Latvia. After the war, the reconstruction of tourism began, however, the attempt to establish a centralized organization was unsuccessful. In the 1960s, a major reorganization of tourism was implemented that led closer to the goal. This study aims to analyse the activities of the Administration of Tourism and Excursions of Latvia and Republican Tourism Council of Latvia. It explains the structure of these institutions and the interaction between units. This work contributes to awareness about the organization of tourism, and also the society of Latvian SSR in the 1960s.

Keywords: Tourism, Latvian SSR, USSR, Administration of Tourism and Excursions of Latvia, Republican Tourism Council of Latvia. 


\section{levads}

Loti liela nozīme ceḷošanai pieškirta ne tikai mūsdienu sabiedrībā - tūrisma nozare spēcīgi iespaido arī pasaules ekonomiku, nodrošinot būtisku daḷu no pasaules valstu iekšzemes kopprodukta un darbvietām. ${ }^{2}$ Tūrismam ir arī politiska nozīme - tas var veicināt integrācijas procesus un sadarbību dažāda mēroga reǵionos, kā arī var liecināt par divu valstu valdību attiecībām. ${ }^{3}$

Par tūrismu sauc darbības, kas saistìtas ar celıšanu un uzturēšanos ārpus pastāvīgās dzīvesvietas brīvā laika pavadīšanas, lietišķo darījumu kārtošanas vai citā nolūkā ne ilgāk kā vienu gadu. ${ }^{4}$ Tūrisma veidi atšķiras atkarībā no tūristu mērkia, pārvietošanās un plānošanas veida.

Padomju Krievijā, vēl izjūtot Pirmā pasaules kara un Krievijas Pilsonnu kara sekas, sākās pievēršanās tūrisma attīstībai - tūrisms tika pārvērsts par ideologijas nostiprināšanas līdzekli sabiedrībā. Tā attīstība bija neviendabīga, ar to nodarbojās daudzas un dažādas organizācijas ar atškirīgiem mērķiem, uzdevumiem un priekšstatiem. ${ }^{5}$ Kā min pētniece Jūlija Rostovskaja (Iuliia Rostovskaia), posmā no Padomju Krievijas dibināšanas līdz 1926. gadam tika radīti pirmie dzelzs priekškara aizmetni, padarot ārējo tūrismu pieejamu tikai noteiktām sabiedrības grupām un popularizējot iekšējo tūrismu plašākai sabiedrības dalaia. ${ }^{6}$ 20. gadu beigās un 30. gadu sākumā precīzāk tika izstrādāti padomju tūrisma pamatprincipi: tūrismam bija jākḷ ūst par "jaunā padomju cilvēka" audzināšanas veidu kolektīvisma garā. ${ }^{7}$ Turpmākajos gados centralizācija kḷuva arvien stingrāka, tūrisma nozarei nonākot Vissavienības arodbiedrību centrālās padomes (VACP) Tūrisma un ekskursiju pārvaldes pakḷautībā.

Latvijas teritorijā jau padomju okupācijas sākumā tūrisms tika izmantots kā padomju propagandas līdzeklis - tas tika iesaistîts 1940. gada Saeimas vēlēšanu aǵitācijas rakstos (par Latvijas darba tautas bloka atbalstī̌sanu). ${ }^{8}$ Pēc Latvijas inkorporācijas sākās tūrisma sovetizācija, ${ }^{9}$ kas pilnībā kḷuva iespējama vien pēc Otrā pasaules kara beigām. Kara rezultātā tūrisma infrastruktūra bija ievērojami cietusi, taču vēl kara pēdējā mēnesī tika pieñemts lēmums turpināt Tūrisma un ekskursiju pārvaldes darbību un atjaunot infrastruktūru.

Kā min PSRS kultūras vēstures speciāliste Ena Gorsača (Anne Gorsuch), pēc Otrā pasaules kara, kad valdijja škietama robežu brīvība, Padomju Savienības valdības ideju par tūrismu varēja raksturot ar vārdiem "nekur nav tik labi kā mājās" - padomju iedzīvotāji tika virzîti uz valsts iekšieni, tālāk no "bīstamajām robežām", tādējādi mazinot Rietumu ietekmi un cenšoties stiprināt padomju patriotisko identitāti. ${ }^{10}$

Latvijas PSR tūrisma organizācija izveidota 1946. gada aprīlī un ar mainīgiem nosaukumiem pastāvēja līdz 1990. gadam. Sākotnēji tās nosaukums bija VACP Tūrisma un ekskursiju pārvalde, 1951. gadā to pārdēvēja par VACP tūrisma un ekskursiju Latvijas pārvaldi. 1960. gadā - par Latvijas tūrisma un ekskursiju pārvaldi (LTEP), bet tā joprojām palika VACP pakḷautība. ${ }^{11}$ Tūrisms nepiedzìvoja uzplaukumu uzreiz pēc kara, taču PSRS tūrisma vēstures pētnieks Grigorijs Usikins (Grigorii Usykin) saskatīja situācijas uzlabošanos un tūrisma popularizēšanos jau 60. gadu sākumā, ${ }^{12}$ tāpēc tas izvēelēts arī kā darba hronologiskā ietvara sākums. 1962. gadā organizācija tika pārdēvēta par Latvijas republikānisko tūrisma padomi (LRTP), bet pēdējo reizi pārdēvēta un reorganizēta 1969. gadā par Latvijas republikānisko tūrisma un ekskursiju padomi, ${ }^{13}$ kas arī iezīmē šì pētijjuma hronologisko beigu robežu. Lìdz 1962. gadam ar tūrisma organizēšanu paralēli nodarbojās vairākas organizācijas, no kurām dala tika likvidētas, izveidojot LRTP, kas kluva par centrālo tūrisma jomas pārvaldītāju. 
Lai arī tūrisms mūsdienās kḷuvis par nozīmīgu tautsaimniecības dalu, ${ }^{14}$ tomēr tā vēsture Latvijas PSR ir mazāk pētīta salīdzinājumā ar Krievijas padomju perioda un Rietumvalstu 20. gadsimta tūrismu. Pētījuma mērkisis ir analizēt LTEP/LRTP darbību 20. gadsimta 60. gados, nosakot darbības sasniegumus un trūkumus. Tas sniedz ieskatu tūrisma attīstībā LTEP/LRTP darbības ietekmē, izmaiṇās organizācijā un tās struktūrā, veicina izpratni par tūrisma organizēšanas un infrastruktūras attīstību, kā arī Latvijas PSR tūrisma attīstības iederību kopējās Padomju Savienības tendencēs. Zināšanas par tūrisma vēsturi palīdz veidot pasaules uztveri, šĩ joma ir pazīstama visā pasaulē - tas ir starptautisks fenomens, ${ }^{15}$ kas vieno cilvēkus laikā un telpā, nenemot vērā atškikirības. Tūrisma pētniecība palīdz saskatīt arī ikdienišḳu aktivitāšu saikni un noškirtību no citiem politiskiem un ekonomiskiem procesiem pasaulē un konkrētās valstīs.

Rakstā izmantoti Latvijas Nacionālā arhīva Latvijas Valsts arhīva 1755. fondā pieejamie dokumenti - dažādu tūrisma organizāciju dokumenti un grāmatvedības materiāli. Izmantoti arī vairāki preses izdevumi, kuros atainotas tūrisma jomas aktualitātes, pētāmo organizāciju darbība un problēmas. Zinātniskajā literatūrā pētāmo organizāciju darbība apskatītajā periodā Latvijas PSR nav atainota, rakstā izmantoti padomju tūrisma pētnieka G. Usikina, periodiskās preses pētnieces J. Rostovskajas un PSRS kultūras vēstures speciālistes E. Gorsačas darbi. Ārzemju tūrismu Latvijas PSR ir pētijusi Ineta Lipša. ${ }^{16}$

\section{Latvijas tūrisma un ekskursiju pārvaldes darbība}

\section{Uzdevumi un pienākumi}

40. un 50. gados lielāko ieguldījumu tūrisma jomas attīstībā deva atsevišḳas sekcijas uzṇēmumu un organizāciju fizkultūras kolektīvos, bet 1960. gadā daḷa tūrisma organizēšanas uzdevumu tika pārvirzīti Latvijas tūrisma un ekskursiju pārvaldes pārzin̄ā, cerot uz ievērojamāku attīstību tieši virsorganizācijas - VACP - dēḷ, kurai bija pieejami lielāki materiālie līdzekḷi un vairāk darbinieku. ${ }^{17}$

LTEP darbība ilga vien divus gadus, organizācijas nosaukums grozīts bieži, taču darbības oficiālie uzdevumi bija visai nemainīgi: organizēt tūrismu un ekskursijas republikas robežās, tai skaitā propagandēt padomju ideologijas pamatnostādnes, iepazīstinot strādniekus ar padomju tautu vēsturi un kultūru, ekonomiku, geogrāfiju, dabas bagātībām, sagatavot tūrisma nozares darbiniekus, vadīt tūristu klubus, būvēt, uzturēt, vadīt un finansēt tūrisma infrastruktūru (viesnīcas, tūristu bāzes un patversmes, ekskursiju bāzes, inventāra nomas punktus, filiālsaimniecības u. tml.), ${ }^{18}$ organizēt ceḷojumus un ekskursijas, kā arī sagatavot tūristus nozīmītes "PSRS tūrists" saņemšanai, organizēt un realizēt konsultācijas par tūrisma un ekskursiju jautājumiem. ${ }^{19}$ 60. gadu sākumā īpaša uzmanība tika pievērsta tūrisma sekciju izveidei dažādās rūpnīcās un citās darbavietās, kā arī tūrisma sacensību organizācijai un līdz ar to - sekciju un klubu darbam un nozīmīšu ieguvēju skaitam. ${ }^{20}$ Nozīmīšu sistēmu jau 30. gadu beigās izveidoja VACP tūrisma un ekskursiju pārvalde, lai motivētu tūristus turpināt sevi fiziski attīstìt. ${ }^{21}$ Nozīmīti "PSRS tūrists" varēja saņemt jebkurš pilngadīgs pilsonis, kuram bija vismaz divu gadu pieredze tūrismā ar vismaz 2-3 izietiem noteiktas grūtības maršrutiem un kurš varēja pierādīt savas teorētiskās un praktiskās spējas pēc speciālas tūrisma programmas apgūšanas. ${ }^{22}$

Organizācijai bija jādarbojas pēc VACP noteiktā aprēḳina, tā saskaṇā ar likumu konkrētajā situācijā drīkstēja rīkoties patstāvīgi - izmantot tai pieškirtos īpašumus, 
savā vārdā slēgt līgumus un citus darījumus, iegūt jaunus īpašumus. ${ }^{23}$

Tiešā vadība bija jānodrošina VACP Centrālās tūrisma un ekskursiju pārvaldes ieceltajam organizācijas priekšniekam, kurš bija atbildīgs par tūrisma organizācijai uzdoto uzdevumu un plānu izpildi, ievērojot finanšu un saimniecisko lietu un vienošanos izpildi. Priekšniekam bija jāizstrādā un jāiesniedz saimniecības-finanšu plāns, jaunie celtniecības, paplašināšanās, organizācijas saimniecību un uznēmumu rekonstrukciju plāni, kapitālā remonta un atjaunošanas plāni, informācija par personālu un administratīvās pārvaldes izdevumiem. ${ }^{24}$ Viṇš bija atbildīgs par visām organizācijas pārvaldībā esošām materiālām vērtībām (lîdzekḷiem no pakḷautībā esošajām saimniecībām un uzṇēmumiem, kredītiem, bankas kontiem u. tml.). ${ }^{25}$

LTEP darbību ietekmēja jaunais padomju ideologiizācijas vilnis, kas sākās ar septingades plāna pien,emšanu 1959. gadā un nostiprinājās līdz ar pārstrādātās Komunistiskās partijas programmas pieņemšanu 1961. gadā. Kā min tiesību zinātnieks Rūdolfs Šlēzingers (Rudolf Schlesinger), partijas programmas bija ne tikai teorētiski koncepti, bet arī vieni no kanāliem, pa kuriem šî teorija var tikt îstenota praksē. ${ }^{26}$ Jaunajā programmā uzsvērta virzība uz komunismu kā cilvēces attīstības ceḷu un komunistiskās sabiedrības celšanu. Vēl lielāks uzsvars likts uz padomju tautību vienotības palielināšanu, kā arī izvairǐšanos no kodolkara. R. Šlēzingers to nosauca par virzīšanos uz komunistiskās sabiedrības attīstību miermīlīgas sāncensības laikā, ${ }^{27}$ ko var vērtēt kā atbilstošu aukstā kara detente periodam, ja neskaita Kubas raķešu krīzi vien gadu pēc programmas pieņemšanas. Saasinājums ASV un PSRS attiecībās vērojams arī pēc padomju valdības pastiprinātas uzmanības pievēršanas t. s. masu aizsardzības darbam, kā rezultātā arī LTEP darbiniekiem bija jāpiedalās civilās aizsardzības programmā, iegūstot GPA ${ }^{28}$ otro pakāpi. ${ }^{29}$

Šì programma noteica LTEP darbības mērḳus un tūrisma pasākumu ideologiskos uzsvarus - Krievijas Pilsoṇu kara un Otrā pasaules kara Austrumu fronte $\bar{e}^{30}$ heroizēšana, masu tūrisma un ekskursiju kā patriotiskās audzināšanas attīstǐšana. ${ }^{31}$ Viens no partijas pamatuzdevumiem bija panākt pilnīgu kopību, sociālo viendabību un draudzību starp Padomju Savienības tautām. Arī šajā gadījumā tūrisms kḷuva par šī mērḳa sasniegšanas metodi. LTEP bija jāpadara tūrisms par masveidīgu, aktīvu brīvā laika pavadīšanas veidu, kas pieejams jebkura vecuma un fiziskās sagatavotības cilvēkam. ${ }^{32}$

Saistībā ar partijas programmu jāpievērš uzmanība tūrisma saiknei ar valsts ekonomiku. Šajā laika posmā pēc N̦ikitas Hruščova (Nikita Khrushchev) iniciatīvas izstrādātais septingades plāns bija tik ambiciozs, ka izrādījās nesasniedzams. Tūrisms bija atkarīgs no ražošanas un celtniecības jomām - nepieciešamā apgéerba un inventāra ražošanas, tūrisma infrastruktūras būvēšanas dažādu bāzu, staciju, satiksmes ceḷu un līdzekḷu formā. Ja tūrisma organizācijai trūka resursu, tā nevarēja izpildīt arī savus darba plānus. Grūtības darba plāna izpildīšanā var saskatīt Latvijas tūrisma un ekskursiju pārvaldes gada atskaitēs, kurās atsevišķi apskatīts pašas pārvaldes un atsevišḳu tūristu bāzu darbs. 1960. gadā lielākā daḷa mērḳu netika sasniegta, netika apkalpots pietiekams skaits tūristu ar ceḷazīmēm, bija pārsniegta tūristu apkalpošanas pašizmaksa, kā dēḷ 1960. gadā pārvaldes parādi bija palielinājušies par 27 tūkstošiem rubḷu. ${ }^{33}$ Lìdzīgas grūtības vērojamas arī 1961. gadā. ${ }^{34}$

Liela uzmanība tika pievērsta kvalifikācijas jautājumiem - ne vien darbinieku, bet arī tūristu vidū. Cenšoties palielināt tūristu skaitu, parādījās ievērojamas tūrisma drošības problēmas, jo jaunie tūristi mēdza, 
piemēram, doties pārgājienos, īsti neizprotot pareizu tūrisma tehniku. Kā liecina raksti preses izdevumos, radās nelaimes gadījumi, kurus nenovērsa pat šo tūristu škiietamā sagatavotība (nozīmītes "PSRS tūrists", nokārtoti sporta klases normatīvi). ${ }^{35}$ LTEP bija jārealizē virkne preventīvu pasākumu, piemēram, katrai tūristu grupai jāpiešḳir apmācīti instruktori, jāorganizē drošības instruktāžas, ${ }^{36}$ grupām jānodrošina medicīniskais personāls. ${ }^{37}$

LTEP darbības laikā sākās regulāra ekskursiju vadītāju apmācīšana un darba novērtēšana. LTEP paklautībā tika izveidota Atestācijas un kvalifikācijas komisija, kurai bija jānosaka vadītāju sagatavotība un jāpieškiir attiecīgā kvalifikācija. Tika nolemts, ka visiem pirmoreiz ekskursiju darbā pieņemtajiem ekskursiju vadītājiem ir jāiziet atestācija, kur piešķīra kvalifikāciju ar trīs gadus derīgu apliecinājumu, ${ }^{38}$ ko apstiprināja Latvijas Republikāniskā arodbiedrību padome, Latvijas PSR Kultūras ministrija un Rīgas pilsētas darbal̦aužu deputātu padomes izpildkomiteja. 1961. gada nogalē tika lemts par stingrāku ekskursiju vadītāju pašizpausmju ierobežošanu ekskursiju laikā - pārvaldei bija jāizveido kontroles teksti un ieteicamās literatūras saraksts katram maršrutam. ${ }^{39}$ Kvalifikācijas celšanas nolūkos uz kursiem un kopsapulcēm Maskavā un L̦eņingradā regulāri devās pārvaldes priekšnieks, vecākais instruktors, grāmatvedis, kā arī tūristu un ekskursiju bāzu direktori un atsevišḳi instruktori. ${ }^{40}$

\section{Struktūrvienības}

LTEP pārziñā bija vien pāris tūristu bāzes, lai gan Latvijas PSR teritorijā bija lielāks skaits tūristu bāzu. Daḷa no tām atradās Vissavienības L Leñina komunistiskās jaunatnes savienības (VḶKS) ${ }^{41}$ un Latvijas PSR Izglīiības ministrijas Republikāniskās bērnu ekskursiju un tūrisma stacijas pārvaldībā. ${ }^{42}$
1961. gadā Latvijas tūrisma un ekskursiju pārvaldes pakḷautībā tika izveidota Rīgas ekskursiju bāze, kurai bija jāorganizē ekskursijas pa republiku (ar uzsvaru uz brīvdienu tūrismu), autobusu, vilcienu un tvaikoṇu īrēšana tūrisma un ekskursiju pasākumiem, jānodrošina tūrisma un ekskursiju reklamēšana, plakātu, afišu un prospektu izdošana saskaṇā ar finanšu plānu. ${ }^{43}$ Rīgas tūristu bāzei bija jāpiešḳir Rīgas ekskursiju bāzei inventārs, naudas līdzekḷi, nepieciešamie dokumenti, kā arī vairāki štata darbinieki.

Atsaucoties uz 1961. gada Padomju Savienības Komunistiskās partijas 22. kongresa un Latvijas Komunistiskās partijas 18. kongresa lēmumiem, Rīgas ekskursiju bāze plaši izvērsa tūrisma attīstību Rīgā. Bāzei bija pavēlēts izstrādāt 12 jaunu maršrutu projektus pa Rīgu, kuros jāpievērš uzmanība republikas strādnieku sasniegumu propagandēšanai, padomju varas gados īstenotajai Rīgas attīstībai rūpniecības, dzīvojamās platības, zinātnes, kultūras un sadzīves jomās, kā arī plānotajai Rīgas attīstišanai "komunisma celtniecības laikā". ${ }^{44}$ 1962. gada maijā jau bija izveidoti septiņi autobusu maršruti, septiņi pārgājienu maršruti, divi tvaikoṇu maršruti, iekḷaujot revolucionāru pieminekḷu vietas, revolūcijas notikumu vietas, Brāḷu kapus, rūpniecības objektus. Kāds maršruts tika veltīts "komjauniešu cīn,ai par padomju varu Latvijā", cits - Rainim, vēl cits - literatūrai, teātrim un arhitektūrai. Ik mēnesi bija jāveic kvalitātes kontrole, jānoklausās gidu stāstījums, nepiel̦aujot neatbilstošas informācijas izplatī̌sanu, ${ }^{45}$ tātad vērojama maršrutu ideoloğizācija.

Pārvalde pieškīra bāzēm līdzekḷus dažādām vajadzībām, piemēram, propagandas darbam, metodiskajam darbam un kadru sagatavošanai. Pieškirtās summas katrai bāzei atškīrās. 1961. gadā vislielākā summa piešķirta Rīgas ekskursiju bāzei (505 rublii), bet mazākā - Rīgas tūristu bāzei un 
Strēlnieku tūristu bāzei (katrai 50 rubḷi). ${ }^{46}$ Ekskursiju vadītāju sagatavošana tika intensīvi plānota, un pārvalde veiksmīgi izstrādāja konkrētu metodiskā darba uzlabošanas plānu, kura rezultātā tika organizēti 10 dienu semināri ekskursiju vadītājiem.

Kā minēts iepriekš, LTEP pārvaldītās tūristu bāzes saskārās ar grūtībām, izpildot darba plānu, - liela daḷa mērḳu palika neīstenota. Mērḳi bija nosprausti divās kategorijās - plānveida tūristu apkalpošana un pašdarbības tūristu apkalpošana. 1960. gadā vissliktāk plānu realizēja tikai tajā gadā pabeigtā Kandavas tūristu bāze, bet vislabāk - Siguldas tūristu bāze. Tikai Rīgas un Siguldas tūristu bāzes bija izpildījušas un pat pārpildījušas noteikto plānu, lai gan arī tikai vienā no kategorijām pašdarbības tūristu apkalpošanā. Tāpat tika pārsniegta plānotā tūristu apkalpošanas pašizmaksa - Rìgas tūristu bāzē par 86,1 tūkstoti, bet Strēlnieku tūristu bāzē par 22,1 tūkstoti rubliu. ${ }^{47}$

LTEP centās kontrolēt arī atsevišksus procesus saistībā ar tūristu bāzu darbiniekiem. Lai gan bāzu darbinieki bija arī pārvaldes štata darbinieki, tomēr bāzu darbiniekus atlaida bāzu direktori. Izmaiṇas šajā procesā notika 1961. gada beigās, kad LTEP tika piešḳirtas pilnvaras atlaist bāzes ekskursiju vadītāju tieši, bez bāzes vadītāja starpniecības $^{48}$ - tas norāda uz ekskursiju vadītāju darba kontroles pastiprināšanu. Kā liela problēma aprakstīta ekskursiju vadītāju pārstrādāšanās vasaras mēnešos. ${ }^{49}$

\section{Latvijas republikāniskās tūrisma padomes darbiba}

\section{Nodaḷas, komisijas un sekcijas}

1962. gada nogalē LRTP priekšsēdētājs Arnolds Ūdris informēja sabiedrību par Latvijas republikāniskās ekskursiju un tūrisma pārvaldes pārdēvēšanu par Latvijas republikānisko tūrisma padomi, intervijā laikrakstam "Cīn,a” norādot, ka iepriekšējā pārvalde bijusi lielākoties saimnieciska organizācija, bet jaunā padome nosaukta par koleǵiālu orgānu, kas izveidots tieši masu darba uzlabošanai un veicināšanai. ${ }^{50}$

LTEP/LRTP un to priekšgājēju štata apmēri bijuši samērā nelieli. Apskatāmā perioda sākumā pārvaldes štats sastāvēja no sešiem cilvēkiem - tie bija pārvaldes priekšnieks, vecākais instruktors, instruktors, galvenais grāmatvedis, grāmatvedis-kasieris, sekretārs-mašīnrakstītājs. Šāds bija pārvaldes oficiālais sastāvs līdz pat 1964. gadam, kad pienēema darbā arī inženieri. To var saistīt ar organizācijas pieaugošajām celtniecības vajadzībām - tika gan projektētas un būvētas jaunas tūristu un ekskursiju bāzes, gan paplašinātas un atjaunotas jau esošās. 1965. gadā LRTP štats tika ievērojami paplašināts, sasniedzot 12 cilvēku kolektīvu. ${ }^{51}$ 1966. gadā kolektīvam pievienojās divi instruktori, ${ }^{52}$ 1967. gadā bija plānots vēl viens darbinieks - galvenā grāmatveža vietnieks, taču gada gaitā pievienojās divi jauni darbinieki - vēl viens inženieris un grāmatvedis. ${ }^{53}$ Padome palika šādā 17 cilvēku sastāvā līdz 60. gadu beigām, tātad apskatītajā periodā organizācijas darbinieku skaits gandrīz trīskāršojās.

Štatu sarakstā norādīts padomes sadalijums vairākās nodaḷās - masu tūrisma, tūrisma maršrutu, bāzu celtniecības un ekspluatācijas, plānošanas un finanšu nodaḷā, taču par to darbu LRTP dokumentos informācija nav atainota, fiksētas tikai atsevišḳ personu darbības (komandējumi, atvaḷinājumi, dalība citās nodaḷās, komisijās u. tml.).

17 cilvēki - šis skaitlis neatspoguḷo patieso pārvaldes aktīvistu apjomu, jo daḷu no tiem uzskaitīja atsevišķi, piemēram, tūristu bāzu darbiniekus, vai arī tie vispār neparādās organizācijas štatu sarakstos. Tomēr organizācijas dokumenti apliecina viņu aktīvo dalību tūrisma veicināšanā, lai arī viṇi pārstāv citas organizācijas, viṇiem 
ir cita darbavieta un nodarbošanās, taču viņi lielākoties ir arī šo pašu organizāciju tūrisma sekciju vai pilsētu/rajonu tūristu klubu pārstāvji, lai gan sākotnēji tas uzskaitēs netika minēts. Iespējams, ar to var pamatot iemeslu, kāpēc LRTP priekšsēdētājs to nosauca, kā jau pieminēts, par koleg̣iālu orgānu.

LRTP prezidija pirmās sēdes atskaitē minētas padomes piecas jaunās komisijas. Komisijas bija līdzīgas vēsturiskajā izziṇā norādītajām nodaḷām, taču specifiskākas.

Plānošanas un ekspluatācijas komisija izstrādāja saimniecības-finanšu plānu tūristu un ekskursiju bāzēm un pašai padomei, kā arī plānoja tūristu bāzu kapitālieguldījumus un labiekārtošanu. ${ }^{54}$ Tai bija jāpārbauda apkalpošanas kvalitāte tūristu un ekskursiju bāzēs, to gatavība sezonu sākumā, ${ }^{55}$ kā arī jākontrolē bāzu celtniecība. ${ }^{56}$

Maršrutu un kvalifikācijas komisija plānoja maršrutu tūrismu (kur persona noteiktā laikā jebkurā pārvietošanās veidā veic iepriekš ieplānoto maršrutu pa dažādiem geogrāfiskiem punktiem), ${ }^{57}$ uzskaitīja sporta klasi ieguvušās personas, izskatīja un apstiprināja maršrutus republikas teritorijā, pieņēma un uzraudzīja nozīmīšu pieškiiršanas kārtību, rīkoja seminārus rajonu un pilsētu maršrutu komisiju darbiniekiem. ${ }^{58}$ Šìs komisijas piešķirtās nozīmītes, piemēram, "Padomju tūrists", it kā tika radītas, lai motivētu cilvēkus turpināt fiziski attīstīt sevi, taču, aplūkojot tās normatīvus, var secināt, ka tā bijusi arī rūpēšanās par tūristu drošību un veselību, bet tūrista nosaukums vismaz teorētiski varēja radīt zināmu kopības sajūtu dažādu republiku un tautību tūristiem. 60. gados nozìmīšu sistēmu paplašināja - izveidoja nozīmīti "LRTP tūrists", kuras iegūšana kḷuva par vienu no normatīviem, kas jāizpilda, lai iegūtu nākamās, "PSRS tūrists" nozīmītei izveidotās pakāpes (III, II un I), bet tālākais sasniegums bija kḷūt par PSRS tūrisma meistara kandidātu, tad - par PSRS tūrisma meistaru. ${ }^{59}$ 1967. gada nogalē uzsākta jaunas nozīmītes izveide - "Latvijas PSR tūrists". ${ }^{60}$ Sadarbībā ar Masu sporta veidu sekciju šì komisija organizēja konsultācijas tūristiem par dažādiem tūrisma veidiem. ${ }^{61} 1963$. gada nogalē šĩs komisijas sastāvs tika paplašināts, piebiedrojoties auto-moto tūrisma pārstāvjiem. ${ }^{62}$

Atestācijas un metodiskā darba komisija (vēlāk - Kadru un atestācijas darba komisija) ${ }^{63}$ pieškīira kvalifikācijas, veica uzskaiti par instruktoru un tiesnešu dalību kursos un semināros, regulēja pārtestēšanu, ${ }^{64}$ veidoja mācību plānus, ieteicamās literatūras sarakstus, plānoja maršrutus Rīgā un tās apkaimē vidējās un vecākās paaudzes cilvēkiem, piedalījās un organizēja tūristu vakarus, sastādīja konkursu nolikumus. ${ }^{65}$ Dokumentācijā vērojama šīs komisijas ciešā sadarbība ar Maršrutu un kvalifikācijas komisiju un Rīgas pilsētas tūristu klubu, kur komisijas pārstāvjiem bija jāsniedz konsultācijas. ${ }^{66}$

Masu tūrisma darba komisija (vēlāk Organizatoriskā-masu komisija) bija atbildīga par jaunu tūrisma kadru sagatavošanas plāna un masu pasākumu plāna izveidi, par LRTP drukāto izdevumu saraksta uzturēšanu, svarīgāko tūrisma materiālu tulkošanu latviešu valodā un izplatīšanu, ${ }^{67}$ par tūristu konferenču organizēšanu, tūrisma sekciju veidošanās veicināšanu fizkultūras kolektīvos, ${ }^{68}$ par tūristu klubu nolikuma sastādīšanu un papildināšanu, kā arī pilsētu un/vai rajonu tūristu klubu izveidi (1963. gadā tapa pirmie pieci klubi Rīgā, Liepājā, Daugavpilī, Jelgavā un Ventspilī, ${ }^{69}$ 1967. gadā - jau $30^{70}$ ). Svarīgākais pasākums, ko organizēja šì komisija, bija Latvijas un Baltijas tūristu ikgadējie salidojumi.

Propagandas un aǵitācijas komisija bija atbildīga par visiem darbiem saistībā ar medijiem un publicitāti - par tūrisma rubrikām laikrakstos, radio un televīzijā, tai bija jāsastāda publicējamās literatūras, 
plakātu un prospektu piedāvājumi, jāveido informatīvie stendi Latvijas PSR lielākajās pilsētās. 1963. gadā tika uzsākti mēginājumi organizēt mediju iestādēs savas arrpusštata nodal̦as, ${ }^{71}$ taču šì uzdevuma izpilde aizkavējās. ${ }^{72}$ Uzlabojumu publicitātes jautājumos var saskatīt 1964. gada otrajā pusē, kad šì komisija jau veidoja masu tūrisma propagandas plānu sadarbībā ar dažādiem medijiem. ${ }^{73}$

LRTP prezidija pirmajā sēdē tika dibinātas arī piecas jaunas sekcijas.

Telšu pilsētiņu tūrisma un veselības nostiprināšanas (Atpūtas nometnuu) sekcija sadarbojās ar Atestācijas un metodiskā darba komisiju un dažādām Rīgas organizācijām un uzṇēmumiem, lai organizētu masu tūrisma pasākumus telšu pilsētiṇās, tai bija arī jāpievēršas pastāvīgai tūrisma propagandēšanai medijos. ${ }^{74}$ Sekcija sadarbojās ar Latvijas PSR Ministru padomi, cenšoties iegūt zemes îpašumus, kur būvēt šīs nometnes, ${ }^{75}$ tādēl, 60. gados arvien mazāk tūristu bāzu telpu bija jāīrē - LRTP spēja iegūt tās savā īpašumā. Vairumā gadījumu sekcijas darbs vērtēts kā l̦oti produktīvs, tas ietvēra idejiski politiskās, audzinošās un sporta aktivitātes (tikšanās ar dažādu profesiju pārstāvjiem, lekcijas, referātu lasījumi, sarunas, sporta sacensības, pārgājieni). LRTP arī uzsvēra, ka ne visās nometnēs padarītais darbs vērtējams kā labs. Konstatēti atsevišḳi gadījumi, kad darbs vispār nav veikts. ${ }^{76}$ Tātad, tāpat kā iepriekšejos periodos, darbs bija loti atkarīgs no personu iniciatīvas un vēlmes darboties. Šādās atpūtas nometnēs arī varēja nokārtot sporta klases, saṇemt nozīmītes un iegūt tiesneša vai instruktora kvalifikāciju - viņi tika nodarbināti tuvējās mežsaimniecībās, kolhozos un sovhozos: tas tikai paspilgtina un parāda, kā realitātē izpaudās padomju presē bieži izteiktā doma, ka fizisks darbs svaigā gaisā ir vislabākā atpūta. ${ }^{77}$

Bērnu un skolu (Bērnu un jaunatnes) tūrisma sekcijas darbinieki pēc profesijas bija ḷoti atbilstoši šĩs sekcijas darba specifikai. To vadīja Republikāniskās bērnu ekskursiju un tūrisma stacijas direktore, tajā darbojās Pionieru pils un Skolotāju nama tūristu kluba pārstāvis, Rēzeknes rajona tautas izglìtības nodaḷas darbinieks, kā arī vairāki vidusskolas skolotāji. ${ }^{78}$ Šì sekcija organizēja un vadīja dažādus konkursus tūrisma veicināšanai, pionieru vadītāju seminārus, jauno tūristu salidojumus, jauno tūristu vakarus, kā arī veica sistemātisku darbu nozīmnieku "PSRS tūrists" un "Jaunais pionieris" sagatavošanā. ${ }^{79}$ Vērienīgākie masu pasākumi bija saistīti ar ideologiskajiem svētkiem, piemēram, 1963. gadā tā organizēja novadpētniecības ekspedīciju, kas bija veltīta Padomju Savienības Komunistiskās partijas sešdesmitgadei, 1969. gadā - Lenina 100. dzimšanas dienai. ${ }^{80}$ Atkarībā no svinamajām dienām šai sekcijai arī bija jānosaka svarīgākie skolās apskatāmie novadpētniecības jautājumi. ${ }^{81}$ 1966. gadā tika uzsākta virzība uz tālāku vienotības nostiprināšanu bērnu tūrisma jautājumos, kā rezultātā, apvienojot LRTP, Latvijas PSR Izglītības ministrijas un vairāku citu organizāciju spēkus, tika izveidota Republikāniskā bērnu un jaunatnes tūrisma metodiskā padome, lai uzlabotu situāciju ar tūrismu vispārizglītojošās skolās, un tā aizvietoja šo sekciju. ${ }^{82}$

Masu tūrisma veidu sekcija bija sadalìta trīs apakšsekcijās pēc tūrisma veida: ūdens tūrisms, kājnieku un slēpošanas tūrisms, kalnu un taigas tūrisms. Katras apakšsekcijas pienākumos ietilpa pasākumu organizēšana, piemēram, tūristu vai atskaites vakaru organizācija, semināru organizēšana grupu vadītājiem, praktisko nodarbību organizēšana tūristiem iesācējiem, dažādu uzskaišu sastādīšana (republikas fizkultūras kolektīvu, tūristu uzskaite, pārgājienu/maršrutu kartotēkas), kā arī tūristu informēšana par pakāpju iegūšanu. ${ }^{83}$ Apakšsekcijām nācās sadarboties ar Atestācijas un metodiskā darba komisiju, 
strādājot pie jauno instruktoru apmācībām, kā arī jāpalīdz Rīgas pilsētas tūristu bāzei izvēlēties pasniedzējus apmācībām. ${ }^{84}$ To pienākumos ietilpa arī pētniecības darbs izzināt atšķirīgus Latvijas PSR apvidus, lai atrastu piemērotas vietas dažādu tūrisma veidu maršrutiem. ${ }^{85}$ Ūdens tūrisma sekcija nodarbojās ar savai specifikai atbilstošiem uzdevumiem, piemēram, tai bija jāizveido Latvijas upju klasifikācija, jāizstrādā atbilstoša treniṇprogramma, kā arī peldēšanas prasmju pārbaudes noteikumi. ${ }^{86}$ İpaši jāizcel̦ Kalnu un taigas tūrisma apakšsekcija, kurai bija visvairāk darba uzdevumu - tas saistāms ar Latvijas PSR iedzīvotāju pieredzes trūkumu šajā jomā. Liels uzsvars tika likts uz pieredzes apmaiṇu ar šādām sekcijām citās republikās, specifisku treniṇu organizēšanu ar nakšn,ošanu ziemas apstākḷos un ar alpīnistiem, alpīnisma teorijas apgūšanu, fizisko un teorētisko normatīvu izstrādi. Būtībā tika veicināta tūristu drošība, tai skaitā analizējot nelaimes gadījumus. ${ }^{87}$ 1963. gada nogalē Masu tūrisma veidu sekcija tika reorganizēta un apakšsekcijas kḷuva par patstāvīgām sekcijām, jo iepriekšējais iedalījums izrādījās neefektīvs, ${ }^{88}$ bet pienākumus gan tas nemainīja.

Autotūrisma (Auto-moto tūrisma) sekcija organizēja un vadīja sekcijas darbu, sastādīja un izplatīja Latvijas PSR auto-moto maršrutu brošūras, nodrošināja motociklu rezerves detalı u pieejamību. ${ }^{89}$ Šìs sekcijas darbību apliecinošie materiāli parādās, sākot ar 1963. gadu. Kopumā tās pienākumi atbilda citu tūrisma veidu sekciju darbam, tai skaitā sacensību ${ }^{90}$ un konkursu organizēšana ("labākais auto-moto tūrists" u. c.). ${ }^{91}$

Arī Ekskursiju darba sekcijas darbību apliecinošie materiāli parādās 1963. gadā. Šai sekcijai bija pakḷauta Rīgas ekskursiju bāze un tās filiāle Jelgavā, kas izveidota 1964. gadā. Šì sekcija izstrādāja šo bāzu maršrutus, izvēlējās un sagatavoja darbiniekus, organizējot seminārus gidu kvalifikācijas uzlabošanai, veidoja un pārbaudīja ekskursiju kontroles tekstus, ${ }^{92}$ sagaidīja tūristu vilcienus no citām PSRS republikām, rīkoja fotokonkursus un atskaites vakarus, organizēja ceḷojumus komunistiskā darba brigādēm. ${ }^{93}$ Viens no spilgtākajiem piemēriem gidu sagatavošanā 60 . gados saistīts ar zinātniski ateistisko propagandu baznīcu arhitektūras pieminekḷu ekskursijās. ${ }^{94}$ Lēmumu par šādu apmācību pieņēma Centrālās tūrisma padomes Ekskursiju darba komisija. Tika uzsvērts, ka viss, kas saistīts ar baznīcu, jāparāda kā mākslas un cilvēces attīstības posms, ko radījusi tauta, nevis baznīca kā organizācija, tādējādi cenšoties atṇemt baznīcām svētuma aspektu..$^{95}$ Minēti arī konkrēti pozitīvie piemēri no ekskursijām Latvijas PSR, piemēram, ekskursijā Doma baznīcā gidiem bija jāstāsta par baznīcas kontrrevolucionāro lomu nacistiskās okupācijas laikā. Tāpat gidiem bija jāizcel sociālā nevienlīdzība un reliǵisko svētku un tradīciju audzinošā nozīme, kamēr, aprakstot jaunos padomju svētkus un tradīcijas, audzinošo raksturu pieminēt nedrīkstēja. ${ }^{96}$

Šo sekciju un komisiju vadītāji kopā ar LRTP priekšsēdētāju veidoja LRTP prezidiju, kas apstiprināja lēmumus, darba plānus, izdevumu tāmes, atskaites, nolikumus ${ }^{97}$ un būtībā sabiedrības priekšā atbildēja par tūrisma attīstības jautājumiem. Proti, kad nenotika pietiekami ātra izaugsme, tieši prezidijs saṇēma pārmetumus preses rakstos. ${ }^{98}$ Nodaḷas, komisijas un sekcijas kopīgi organizēja tūristu bāzes un ekskursiju bāzes (60. gadu otrajā pusē pārveidotas sākotnēji par ekskursiju birojiem, bet drīz pēc tam par ekskursiju un cel̦ojumu birojiem), arī pilsētu un/vai rajonu tūristu klubus.

Komisijas, sekcijas un tūristu klubi savstarpēji sadarbojās, arī organizējot apmācības un masu pasākumus. Padomei bija jāinformē savas struktūrvienības par Centrālās tūrisma padomes lēmumiem. Katrā tūristu klubā bija izveidotas savas komisijas saskaṇā ar LRTP komisiju 
struktūru, kurām tās atskaitījās. LRTP komisijas arī palīdzēja tūristu klubu komisijām dažādos jautājumos.

\section{Bāzes un biroji}

Ekskursijas, pārgājienus un citas tūrisma aktivitātes organizēja tūristu un ekskursiju bāzes: iepriekšējo tūrisma organizāciju izveidotās Rīgas un Siguldas tūristu bāzes (1955), Strēlnieku tūristu bāze (1958), Kandavas tūristu bāze (1960), Rīgas ekskursiju bāze (1961) un pašas LRTP veidotās - Vaivaru tūristu bāze (1964) un Rīgas ekskursiju bāzes filiāle Jelgavā (1964) u. c. ${ }^{99}$ 60. gados LRTP paplašināja arī tūristu bāzu tîklu - no trīs tūrisma bāzēm ar kopumā 350 vietām 1960. gadā ${ }^{100}$ līdz piecām ar 1057 vietām 1969. gadā, ${ }^{101}$ samazinot īrēto tūristu bāzu skaitu attiecīgi no trīs ar 399 vietām ${ }^{102}$ lìdz vienai ar 100 vietām. ${ }^{103} 1965$. gada nogalē tika pieņemts lēmums piešķirt finansējumu vairāku jaunu tūristu bāzu izbūvei Alūksnē un Sauleskalnā, 1966. gadā sāka projektēt tūristu bāzes "Usma", "Ogre", "Ërglì" un "Rīgas Jūrmala", kā arī paātrināt jau iesāktā projekta izstrādi bāzei "Ezernieki". ${ }^{104}$ Bieži bāzu celtniecība ieilga darbinieku nolaidības vai resursu trūkuma dēḷ. Gandrīz visas iepriekš minētās bāzes arī 1969. gadā bija projektēšanas stadijā, ${ }^{105}$ un to celtniecību atlika uz 70. gadiem, kad bija plānota vērienīga bāzu tîkla paplašināšana un trīs tūrisma joslu izveidošana Latvijas PSR teritorijā. ${ }^{106}$

60. gados palielinājās tūristu un ekskursiju bāzēs nodarbināto personu skaits. Dekādes sākumā bija nodarbinātas 126 personas, ${ }^{107}$ bet 1969. gadā jau 218. ${ }^{108}$ Nodarbināto skaita palielināšanās nebija lineāra - atsevišḳos gados vērojama skaita samazināšanās.

Organizējot tūristu pasākumus, padome mēdza piesaistīt bāzu darbiniekus un uz bāzu rīkotajiem pasākumiem sūtīt pārvaldes darbiniekus. Padomes instruktori regulāri tika sūtīti uz tūristu bāzēm dažādos uzdevumos, fiksēti precīzi uzdevumi, citkārt - vispārināti, piemēram, "sniegt tūrisma - ekskursiju palidzību". ${ }^{109}$ Instruktori tika izmantoti kā papildpersonāls bāzēs, kad grupu skaita dēḷ ar bāzu darbiniekiem nepietika. ${ }^{110}$

Uz bāzēm tika sūtīti ne vien instruktori, bet arī grāmatveži, lai veiktu bāzu dokumentācijas revīziju. ${ }^{111}$ Gandrīz katrā revīzijā konstatēti vairāki pārkāpumi, un šo situāciju neizdevās labot līdz pat apskatāmā perioda beigām. ${ }^{112}$

Lai stimulētu darbu, arī tūristu bāzu ietvaros tika organizēta sociālistiskā sacensība (katras profesijas pārstāvjiem). 60. gados darbiniekus biežāk apbalvoja ar diplomiem, labākos izcēla uz goda dēḷiem, arī bāzes darbs vispār bija pakārtots ideologisisajiem svētkiem. ${ }^{113}$

Dokumentācijā parādās tādi darbības trūkumi kā nepietiekama gatavība noteiktiem pasākumiem. Piemēram, 1964. gadā Rīgas ekskursiju bāze san̄ēma pārmetumus no LRTP par to, ka nav gatava Latvijas PSR $^{114}$ un Oktobra revolūcijas gadadienu svinībām. ${ }^{115}$ LRTP turpināja atgādināt bāzu direktoriem par viņu atbildību situācijas kontrolēšanā, taču tādi gadījumi turpinājās. ${ }^{116}$ Par bezatbildību pārmetumi vairākkārt izteikti Rīgas ekskursiju bāzei, ipaši pēc direktora kabineta apzagšanas 1964. gada septembrī. ${ }^{117}$

Avotos parādās l,oti atšķirīga statistika par bāzu apkalpoto tūristu skaitu, tas, iespējams, saistāms ar nepareizu vienību nolasīšanu no atskaitēm vai to nepārveidošanu. Kopumā reālistiskākais uzskaitījums varētu būt šāds: 1962. gadā tūristu bāzes kopumā apmeklēja 14 tūkstoši cilvēku un ekskursijās piedalījās 184 tūkstoši, ${ }^{118}$ bet 1969. gadā Latvijas tūrisma bāzes apmeklēja vairāk nekā 10 tūkstoši tūristu, kas ceḷoja pa vissavienības maršrutiem, 14 tūkstoši - pa vietējiem, un 65 tūkstoši - pa individuāliem maršrutiem, bet 700 tūkstoši 
devās ekskursijās. ${ }^{119}$ Šie skaitḷi parāda visai ievērojamu izaugsmi.

1965. gadā tika izveidots Rīgas pilsētas ekskursiju birojs ${ }^{120}$ (tajā pašā dienā pārsaukts par Rīgas pilsētas ceḷojumu un ekskursiju biroju), ${ }^{121}$ tika dibināts arī Jūrmalas ekskursiju birojs un likvidētas attiecīgo pilsētu ekskursiju bāzes. ${ }^{122}$ Biroju uzdevums bija apkalpot strādnieku ekskursijas, ekskursiju laikā propagandēt padomju varas iestāžu lēmumus, kā arī iepazīstināt sabiedrību ar padomju valsts vēsturi un dabas bagātībām. Tātad būtībā biroju darbības mērḳi sakrita ar ekskursiju bāzu mērķiem un uzdevumiem (organizēt tūrisma pasākumus, izstrādāt maršrutus), ar struktūru un trūkumiem. Katrā ekskursiju birojā bija ekskursiju nodaḷa, cel̦ojumu nodal̦a, plānošanas un finanšu nodaḷa, ceḷazìmju realizācijas nodaḷa un metodiskā nodaḷa. ${ }^{123}$

Desmitgades sākumā nepietika apmācītu darbinieku, ${ }^{124}$ taču 1968. gadā situācija bija uzlabojusies, un gidi ne vien piedalījās speciālajās lekcijās, bet lielākā daḷa arī bija ieguvuši augstāko izglītību vēsturē un filozofijā, daḷai bija tehniskā augstākā izglītība, bet pārējie bija šādu izglītības iestāžu studenti, kā arī visi bija izgājuši atestāciju. ${ }^{125}$

Bāzu un biroju darbi lielākoties ir l,oti birokratizēti un atspogulo tikai konkrêtus faktus, tomēr tūristu plēnumu materiālos var saskatīt dažas liecības par organizāciju savstarpējām attiecībām. 1968. gada tūristu plēnumā izvērsās diskusija par Rīgas un Jūrmalas ekskursiju biroju attiecībām, kas nosauktas par neveselīgām un greizsirdības pilnām. ${ }^{126}$ Daḷa uzskatīja, ka pie šī saasinājuma ir vainojama LRTP, kas it kā ierobežojusi Jūrmalas ekskursiju biroju, lai atbalstītu Rīgas ekskursiju biroja plānus. Arī Rīgas ekskursiju biroja pārstāvji izteica pretenzijas pret LRTP par nepietiekamu biroja nodrošināšanu ar mēbelēm un telpu remontu (līdzīgi arī Daugavpils ekskursiju birojāā $\left.{ }^{127}\right) .{ }^{128}$ Biroja pārstāvis arī iestājās pret LRTP prasību palielināt propagandas darbu, jo to nav bijis reāli paveikt ar tā brīža līdzekliem. Būtībā LRTP ignorēja reālās problēmas, lai vismaz teorētiski tās darbs veidotos atbilstoši Centrālās tūrisma padomes prasībām, un iepriekšminētās sūdzības LRTP nekomentēja. Vērojamas arī personiskas nesaskan,as starp abu biroju vadītājiem. ${ }^{129}$

\section{Secinājumi}

Lai arī padomju tūrisma būtība bija definēta un mērḳi izvirzīti vēl pirms Otrā pasaules kara, Padomju Savienības principiem atbilstošu centralizētu tūrisma organizāciju neizdevās izveidot līdz pat 20. gadsimta 60. gadiem. Reorganizācijas nepieciešamību varēja pamatot vairākos aspektos: 1919. gada Komunistiskās partijas programma vairs neatbilda pastāvošajai situācijai valstī, radās vajadzība pēc jaunas, ${ }^{130}$ un tūrisms kḷva par vienu no kanāliem, pa kuriem programmas teorija varēja tikt izvirzīta praksē. Cits praktisks iemesls - joprojām ar tūrisma organizēšanu nodarbojās vairākas organizācijas, bet tas padarīja darbu neefektīvu un nesaskan,otu. Organizācijas bija nelielas, tām trūka atbilstoša finansējuma, resursu, vienotības. ${ }^{131}$

Latvijas tūrisma un ekskursiju pārvalde savas neilgās darbības laikā sāka virzību uz tūrisma jomas centralizāciju un ideologizāciju. Pēc jaunas Komunistiskās partijas programmas pieņemšanas sākās jauns ideologizācijas vilnis, kas noteica LTEP darbības mērḳus un tūrisma pasākumu ideologiskos uzsvarus un tieši skāra tūrismu, kas Padomju Savienībā tika izmantots kā padomju identitātes un kopējās vēsturiskās atmiņas veicinātājs. Tūrismam bija jākḷūst par daḷu no cilvēka ikdienas - jebkuram pieejamu aktīvu brīvā laika pavadīšanas veidu, kas norūdītu padomju sabiedrību garīgi un fiziski. ${ }^{132}$

Strauja aktīvo tūristu skaita palielināšanās radīja drošības draudus tūristu un 
tūrisma gidu pieredzes trūkuma dēḷ. Lai atrisinātu šo problēmu, LTEP pievērsās savu darbinieku un tūristu kvalifikācijas uzlabošanai. Par normu kḷuva darbinieku dalība apmācībās, medicīnas personāla piesaiste garākos izbraukumos, kā arī drošības instruktāžas un maršrutu grūtības pakāpju ierobežojumi, tas kopumā vērtējams pozitīivi.

1962. gadā notika pirmā būtiskā padomju tūrisma sistēmas reorganizācija kopš 30. gadiem. LRTP jau lielākā mērā izdevās panākt tūrisma darba centralizāciju, pateicoties lēmumam likvidēt daḷu iepriekšējo tūrisma organizāciju, lai izvairītos no paralēlām funkcijām. ${ }^{133}$ LRTP tika izveidota uz LTEP pamata, bet 60 . gadu laikā tā ievērojami paplašinājās gan darbinieku, gan struktūrvienību skaita ziṇā. 60. gadu laikā gandrīz trīskāršojās tās štata darbinieku skaits (no 6 līdz 17), ${ }^{134}$ taču kopējais tūrisma aktīvistu skaits bija lielāks - tie darbojās LRTP komisijās, sekcijās, tūristu bāzēs un ekskursiju birojos. Padomes darbības sākumā tika dibinātas piecas sekcijas un piecas komisijas, kas 60. gadu laikā paplašinājās, daḷa pārorganizējās. Šīs struktūrvienības veica nozīmīgu darbu tūrisma attīstīšanā - maršrutu izstrādē, tūrisma infrastruktūras projektēšanā, tūrisma popularizēšanā un jaunu tūrisma formu ieviešanā (60. gados jāizceḷ autostopa sistēma un auto-moto tūrisms), sabiedrisko tūrisma organizāciju kontrolēšanā, masu tūrisma pasākumu organizēšanā, lai gan nācās saskarties ar daudzām grūtībām - gan nepietiekamā finansējuma dēḷ, gan darbinieku nolaidības vai entuziasma trūkuma dēḷ.

Ievērojami palielinājās arī tūristu bāzu darbinieku skaits - no $126^{135}$ līdz 218 personām. ${ }^{136}$ Nedaudz palielinājās padomes tūristu bāzu skaits - no trīs ar 350 vietām ${ }^{137}$ lìdz piecām ar 1057 vietām, ${ }^{138}$ kas ir pozitīvs rezultāts, lai gan plašāka celtniecība un paplašināšana tika plānota, bet netika realizēta.
Kā LRTP un to struktūrvienību darbības sasniegums jāizceḷ kvalifikācijas jautājumu risināšana. Organizācija sistemātiski strādāja pie tūrisma kadru mācību programmas sastādī̌̌anas un īstenošanas, kas rezultējās ar tautas tūrisma universitātes izveides plānošanu 1965. gada nogalē, ${ }^{139}$ un jau 1966. gada beigās mērkis bija izpildìts - tika izveidota Republikāniskā tūrisma tautas universitāte, kas palielināja augsti izglītotu ekskursiju vadītāju skaitu. ${ }^{140}$

Centienus uzlabot tūristu kvalifikāciju ir grūti novērtēt kā sasniegumu vai trūkumu, proti, mēǵinājumu uzlabot cilvēku teorētiskās un praktiskās zināšanas tūrisma jomā ar nozīmīšu sistēmas palīdzību. Kaut arī šajā pieejā ir sava log̣ika, praksē tas ne vienmēer palīdzēja, jo dažādus incidentus un individuālo reakciju uz tiem ne vienmēr var kontrolēt.

Vairākās jomās tūrisma vadība joprojām bija dalīta, īpaši bērnu un jaunatnes tūrisma jomā sadarbībā ar Ministru padomes Fiziskās kultūras un sporta komiteju, tomēr tas nemazināja padomes darba efektivitāti, kā tas bija 50. gados, bet gan uzlaboja un attīstīja citu tūrisma attīstības ceḷu - tūrismu kā sporta veidu. Pati LRTP stingrāk virzījās uz masu tūrisma attīstību, iekḷaujoties Centrālās tūrisma padomes nospraustajās robežās, kas bez citu organizāciju iesaistes nozīmētu zināmu tūrisma jomas sašaurināšanos.

Kopumā LRTP stingri ievēroja Centrālās tūrisma padomes principus, bet tas ne vienmēr pozitīvi ietekmēja organizācijas darbu. Tūristu plēnumos bieži vien tika izteikta LRTP darbības kritika, pretenzijas un ieteikumi, kuri netika n,emti vērā, ja neiekḷāvās Centrālās tūrisma padomes darbības filozofijā: tas vērtējams kā nopietns darbības trūkums. Tāpat jāievēro šo aktīvistu entuziasms risināt tūrisma jomas problēmas - ambiciozām personām, kuras saistīja šì joma, bija liela nozīme tūrisma attīstības jautājumu virzīšanā arī 60. gados. 


\section{ATSAUCES UN SKAIDROJUMI}

${ }^{1}$ Raksta pamatā ir autores mağistra darbs "Latvijas tūrisma un ekskursiju pārvaldes (Latvijas republikāniskās tūrisma padomes) darbība 20. gadsimta 60. gados" (Latvijas Universitāte, 2020). Darba zinātniskais vadītājs - Jānis Keruss.

${ }^{2}$ World Travel \& Tourism Council. Travel \& Tourism Regional Performance, 2019. Pieejams: https://wttc.org/Research/Economic-Impact (skatīts 20.09.2020.).

${ }^{3}$ LINDA K. RICHTER. The Politics of Tourism in Asia. Honolulu 1989, p. 4. Pieejams arī: https:// www.jstor.org/stable/j.ctv9zcjr9 (skatīts 29.03.2020.).

${ }^{4}$ Latvijas Republikas Saeima. Tūrisma likums. Pieejams: http://m.likumi.lv/doc. php id = 50026\&amp;version_date $=03.11 .1999$ (skatīts 13.01.2020.).

${ }^{5}$ GRIGORI USYKIN. Ocherki istorii rossiiskogo turizma. Obshchestvo proletarskogo turizma i ekskursii (1927-1936). Sankt-Peterburg 2007. Pieejams arī: https://tourlib.net/books_history/ usyskin08.htm (skatìts 20.12.2019.).

${ }^{6}$ IUlIIA RostovskaIA. Turisticheskaia Pressa v SSSR: harakter stanovleniia i razvitiia. In: Voprosy teorii i praktiki zhurnalistiki, T. 7, No. 1. Irkutsk 2018, s. 26.

7 Ibidem, s. 25.

${ }^{8}$ Nodosim visi balsis par labāku rītdienu. In: Brīvā Zeme, 12.07.1940., 4. lpp.

${ }^{9}$ Kā izmanto atpūtu Padomju Savienības pilsoṇi. In: Brīvā Jaunatne, 08.08.1940., 6. lpp.

${ }^{10}$ ANNE Gorsuch. "There's No Place like Home": Soviet Tourism in Late Stalinism. In: Slavic Review 62, 2003, No. 4, p. 760 (Tourism and Travel in Russia and the Soviet Union). Pieejams arì: https://www.jstor.org/stable/3185654?seq = 1 (skatīts 15.01.2020.).

${ }^{11}$ Latvijas republikāniskā tūrisma padome - vēsturiskā izziņa, 07.05.1971. Latvijas Nacionālais arhīvs, Latvijas Valsts arhīvs, Rīga (turpmāk - LNA LVA), 1755, 1.-2. lp.

${ }^{12}$ GRIGORII USYKIN. Ocherki istorii rossiiskogo turizma. Rozhdenie klubov turistov v strane (19571961). Sankt-Peterburg 2007. Pieejams arì: https://bit.ly/3dNIOca (skatīts 03.04.2020.).

${ }^{13}$ Latvijas republikāniskā tūrisma padome - vēsturiskā izziņa, 16.05.1967. LNA LVA, 1755, 3. lp.

${ }^{14}$ Latvijas Investīciju un attīstības aǵentūra. Tūrisms. Pieejams: https://www.liaa.gov.lv/lv/turismanozarei (skatìts 08.01.2020.).

${ }^{15}$ ERIC G. E. ZuELOW. Teaching: Why Tourism History? Midwest Popular Culture Association Annual Conference in St. Louis, MO, October 14-16, 2005. Pieejams: http://ericzuelow.com/ ModernTourism/WhyTourismHistory.html (skatīts 03.01.2020.).

${ }^{16}$ INETA LIPŠA. VDK ietekme un padomju Latvijas ārzemju tūrisma iestāžu vadošais personāls: Vissavienības akciju sabiedrības "Intūrists" Rīgas nodala un tās operatīvā vadība (1957-1992). In: Latvijas Vēstures Institūta Žurnāls 2017, Nr. 2, 80.-128. lpp.

${ }^{17}$ A. KRAstin̦š. Tūrisms šogad. In: Rīgas Balss, 05.01.1960., 5. lpp.

${ }^{18}$ Latvijas republikāniskā tūrisma padome - vēsturiskā izziņa, 16.05.1967. LNA LVA, 1755, 1.-2. lp.

${ }^{19}$ Par tūrisma un ekskursiju pārvaldi VCSPS [krievu val.], 12.06.1951. Ibidem, 1755-1-2, 1. lp.

${ }^{20}$ Protokols Nr. 54 [krievu. val.], 21.01.1960. Ibidem, 1755-1-3, 5. lp.

${ }^{21}$ AleKSANDRA BRIEDE, JeVgeniJs VASIḶJEVs. Fiziskās audzināšanas un sporta teorētiskie un metodiskie pamati. Rīga 1975, 11. lpp.

${ }^{22}$ GRIGORII UsYKIN. Ocherki istorii rossiiskogo turizma. Turistsko-ekskursionnoe delo v predvoennye gody (1936-1941). Sankt-Peterburg 2007. Pieejams arī: https://tourlib.net/books_history/ usyskin09.htm (skatìts 21.12.2019.).

${ }^{23}$ Par tūrisma un ekskursiju pārvaldi VCSPS [krievu val.], 12.06.1951. LNA LVA, 1755-1-2, 1. lp.

${ }^{24}$ Ibidem, 3. lp.

${ }^{25}$ Ibidem.

${ }^{26}$ RUdolPh SCHLESINGER. Marxist Theory and the New Program of the Soviet Communist Party. In: Science \& Society. New York 1962, p. 129.

${ }^{27}$ Ibidem, p. 133. 
${ }^{28}$ Gatavs pretgaisa aizsardzībai.

${ }^{29}$ Pavēle Nr. 14 [krievu val.], 16.04.1962., Rīga. LNA LVA, 1755-1-11, 18. lp.

${ }^{30}$ Avota tekstā - Pilsoṇu karš un Lielais Tēvijas karš.

${ }^{31}$ Par tūrisma un ekskursiju pārvaldi VCSPS [krievu val.], 12.06.1951. LNA LVA, 1755-1-2, 1. lp.

${ }^{32}$ M. KoRUle. Ziņojums par tūrisma masveidības tālāku attīstību, 1963. Ibidem, 1755-2-1, 4. lp.

${ }^{33}$ Pavēle Nr. 5 [krievu val.], 17.03.1961., Rīga. Ibidem, 1755-1-10, 5. lp.

${ }^{34}$ Pavēle Nr. 27 [krievu val.], 27.06.1961., Rīga. Ibidem, 31. lp.

${ }^{35}$ L. TAMAŠIns. Mazā upīte atrieba jūru. In: Padomju Jaunatne, 13.01.1961., 3. lpp.

${ }^{36}$ Pavēle Nr. 16. Saskaņā ar Latvijas Republikāniskā arodbiedrību padomes prezidija dekrētu 1961. gada 20. aprīlī [krievu val.], 20.05.1961., Rīga. LNA LVA, 1755-1-10, 19. lp.

${ }^{37}$ Pavēle Nr. 2. Sakarā ar slēpotāju tūristu vilciena organizēšanu uz Aizkarpatiem no 1961. gada 5. līdz 15. februārim [krievu val.], 03.02.1961., Rīga. Ibidem, 2. lp.

${ }^{38}$ Pavēle Nr. 15 [krievu val.], 10.05.1961., Rīga. Ibidem, 18. lp.

${ }^{39}$ Pavēle Nr. 54 [krievu val.], 27.11.1961., Rīga. Ibidem, 59. lp.

${ }^{40}$ Pavēle Nr. 56 [krievu val.], 01.12.1961., Rīga. Ibidem, 63. lp.; Pavēle Nr. 9 [krievu val.], 24.02.1961., Rīga. Ibidem, 1755-1-11, 11. lp.

${ }^{41}$ Top modernākā tūristu bāze Latvijā. In: Sociālistiskais Ceḷš, 21.06.1960., 2. lpp.

${ }^{42}$ V. Vìtols. Jauno tūristu vasaras bāzes. In: Zemgales Komunists, 20.05.1960., 3. lpp.

${ }^{43}$ Pavēle Nr. 8. Lēmums par Rīgas ekskursiju bāzes dibināšanas tūrisma un ekskursiju pārvaldes ietvaros [krievu val.], 30.03.1961. LNA LVA, 1755-1-10, 10. lp.

${ }^{44}$ Pavēle Nr. 54 [krievu val.], 27.11.1961., Rīga. Ibidem, 58. lp.

${ }^{45}$ Pavēle Nr. 15 [krievu val.], 10.05.1962., Rīga. Ibidem, 1755-1-11, 19. lp.

${ }^{46}$ Pavēle Nr. 21 [krievu val.], 31.05.1961., Rīga. Ibidem, 1755-1-10, 25. lp.

${ }^{47}$ Pavēle Nr. 5 [krievu val.], 17.03.1961., Rīga. Ibidem, 5. lp.

${ }^{48}$ Pavēle Nr. 54 [krievu val.], 27.11.1961., Rīga. Ibidem, 61. lp.

${ }^{49}$ Ibidem, 60. lp.

${ }^{50}$ Ko tūristiem sola nākamais gads? In: Cīṇa, 25.12.1962., 4. lpp.

${ }^{51}$ Štatu saraksts [krievu val.], 15.01.1966., Maskava. LNA LVA, 1755-4-40, 63. lp.

52 Tūrisma padomes štatu saraksts [krievu val.], 1966. Ibidem, 1755-4-43, 13. lp.

${ }^{53}$ Tūrisma padomes štatu saraksts [krievu val.], 1967. Ibidem, 1755-4-46, 12. lp.

${ }^{54}$ Darba plāns [krievu val.], 13.11.1962., Rīga. Ibidem, 1755-1-13, 31. lp.

${ }^{55}$ Plānošanas un ekspluatācijas komisijas darba plāns [krievu val.], 25.04.1963., Rīga. Ibidem, 1755-1-21, 5. lp.

${ }^{56}$ Plānošanas un ekspluatācijas komisijas darba plāns [krievu val.], 10.07.1963., Rīga. Ibidem, 1755-1-15, 75. lp.

${ }^{57}$ M. P. KLJAP, F. F. SHANDOR. Sovremennye raznovidnosti turizma. Moskva 2011, 69. nodalia. Pieejams arī: http://uchebnikirus.com/turizm/suchasni_riznovidi_turizmu__klyap_mp/klasifikatsiya_ turizmu_zasobami_peresuvannya.htm (skatìts 15.05.2020.).

${ }^{58}$ Darba plāns [krievu val.], 13.11.1962., Rīga. LNA LVA, 1755-1-13, 28. lp.

${ }^{59}$ EgONS ZABLOVSKIS, LİGA ZARIN̦A. No Oliṇkalna līdz Everestam. Rīga 1997, 81. lpp.

${ }^{60}$ Lēmums par vienotu krūšu nozīmīti un emblēmu "LATVIJAS PSR tūrists" [krievu val.], 03.11.1967. LNA LVA, 1755-1-40, 190. lp.

${ }^{61}$ Maršrutu un kvalifikācijas komisijas darba plāns [krievu val.], 10.07.1963., Rīga. Ibidem, 1755-1-15, 77. lp.

${ }^{62}$ Protokols Nr. 2 [krievu val.], 28.10.1963., Rīga. Ibidem, 1755-1-16, 37. lp.

${ }^{63}$ Protokols Nr. 2 [krievu val.]., 26.06.1967., Rīga. Ibidem, 1755-1-40, 19. lp.

${ }^{64}$ Atestācijas un metodiskā darba komisijas darba plāns [krievu val.], 01.04.1963., Rīga. Ibidem, 1755-1-15, 16. lp. 
${ }^{65}$ Protokols Nr. 14 [krievu val.], 13.04.1964., Rīga. LNA LVA, 1755-1-20, 26. lp.

${ }^{66}$ Atestācijas un metodiskā darba komisijas darba plāns [krievu val.], 01.04.1963., Rīga. Ibidem, 1755-1-15, 16. lp.

${ }^{67}$ Organizatoriskās-masu komisijas darba plāns [krievu val.], 01.04.1963., Rīga. Ibidem, 18. lp.

${ }^{68}$ Darba plāns [krievu val.], 13.11.1962., Rīga. Ibidem, 1755-1-13, 30. lp.

${ }^{69}$ Protokols Nr. 3 [krievu val.], 09.01.1963., Rīga. Ibidem, 1755-1-14, 4. 1p.

${ }^{70}$ Stenogramma [krievu val.], 25.04.1968., Rīga. Ibidem, 1755-1-42, 5. lp.

${ }^{71}$ Propagandas un aǵitācijas komisijas darba plāns [krievu val.], 01.04.1963., Rīga. Ibidem, 1755-1-15, 15. lp.

72 Propagandas un ag̣itācijas komisijas darba plāns [krievu val.], 25.04.1964., Rīga. Ibidem, 1755-1-21, 9. lp.

${ }^{73}$ Propagandas un ag̣itācijas komisijas darba plāns [krievu val.], 27.07.1964., Rīga. Ibidem, 1755-1-22, 22. lp.

${ }^{74}$ Telšu pilsētinu tūrisma un veselības nostiprināšanas sekcijas darba plāns [krievu val.], 12.11.1962. Ibidem, 1755-1-13, 18. lp.

75 Telšu pilsētiņu tūrisma un veselības nostiprināšanas sekcijas darba plāns [krievu val.], 13.01.1964., Rìga. Ibidem, 1755-1-20, 18. lp.

${ }^{76}$ Lēmums - protokols Nr. 12 [krievu val.], 25.11.1963., Rīga. Ibidem, 1755-1-16, 69. lp.

77 J. LIEPIN̦Š. Jauniešu nometne kolhozā. In: Cīṇa, 01.06.1957., 2. lpp.

${ }^{78}$ Protokols Nr. 2 [krievu val.], 12.11.1963., Rīga. LNA LVA, 1755-1-13, 16. lp.

${ }^{79}$ Darba plāns [krievu val.], 13.11.1962., Rīga. Ibidem, 32. lp.

${ }^{80}$ Protokols Nr. 1 [krievu val.], 27.01.1969., Rīga. Ibidem, 1755-1-46, 1. lp.

${ }^{81}$ Instruktīva vēstule [krievu val.], 1965. Ibidem, 1755-1-29, 42. 1p.

${ }^{82}$ Nolikums [krievu val.], 21.12.1966., Rìga. Ibidem, 1755-1-36, 49. lp.

${ }^{83}$ Darba plāns [krievu val.], 13.11.1962., Rīga. Ibidem, 1755-1-13, 26.-27. lp.

${ }^{84}$ Masu tūrisma veidu sekcijas darba plāns [krievu val.], 01.04.1962., Rīga. Ibidem, 1755-1-15, 25. lp.

${ }^{85}$ Rīkojums Nr. 41 [krievu val.], 15.05.1964., Rīga. Ibidem, 1755-1-19, 43. lp.

${ }^{86}$ Ūdens tūrisma sekcijas darba plāns [krievu val.], 13.01.1964., Rīga. Ibidem, 1755-1-20, 23. lp.

${ }^{87}$ Mācību plāns - programma [krievu val.], 1963. Ibidem, 1755-1-15, 35. lp.

${ }^{88}$ Protokols Nr. 2 [krievu val.], 28.10.1963., Rīga. Ibidem, 1755-1-16, 33. lp.

${ }^{89}$ Auto-moto tūrisma sekcijas darba plāns [krievu val.], 01.04.1963. Ibidem, 1755-1-15, 20. lp.

${ }^{90}$ Protokols Nr. 1 [krievu val.], 27.01.1969., Rīga. Ibidem, 1755-1-46, 1. lp.

${ }^{91}$ Ibidem, 53. lp.

${ }^{92}$ Ekskursiju darba sekcijas darba plāns [krievu val.], 13.01.1964., Rīga. Ibidem, 1755-1-20, 24. lp.

${ }_{93}$ Brigādes, kas sasniegušas augstu darba ražīgumu (Sovetskaia istoricheskaia enciklopediia).

${ }^{94}$ Protokols Nr. 20 [krievu val.], 23.11.1965., Rīga. LNA LVA, 1755-1-27, 1. lp.

${ }_{95}$ Ibidem, 2. lp.

${ }^{96}$ Ibidem, 4. lp.

${ }^{97}$ LRTP prezidija darba plāns [krievu val.], 25.04.1964., Rīga. Ibidem, 1755-1-21, 18. lp.

${ }^{98}$ V. PAEgle. Tūristi gaida atbildi. In: Padomju Jaunatne, 09.01.1963., 3. lpp.

${ }^{99}$ Protokols Nr. 20 [krievu val.], 23.11.1965., Rīga. LNA LVA, 1755-1-27, 4. lp.

${ }^{100}$ Pamatrādītāji [krievu val.], 10.12.1960. Ibidem, 1755-4-29, 8. lp.

${ }^{101}$ Pamatrādītāji [krievu val.], 27.11.1968. Ibidem, 1755-4-50, 21. lp.

${ }^{102}$ Pamatrādītāji [krievu val.], 10.12.1960. Ibidem, 1755-4-29, 8. lp.

${ }^{103}$ Pamatrādītāji [krievu val.], 27.11.1968. Ibidem, 1755-4-50, 21. lp.

${ }^{104}$ Protokols Nr. 6 [krievu val.], 29.11.1965., Rīga. Ibidem, 1755-1-31, 59. lp. 
${ }^{105}$ Protokols Nr. 10 [krievu val.], 29.09.1969., Rīga. LNA LVA, 1755-1-48, 87. lp.

${ }^{106}$ Latvija - tūrisma novads. In: Komunisma Rìts, 29.07.1969., 4. lpp.

${ }^{107}$ Pielikums Nr. 26 [krievu val.], 22.01.1960., Maskava. LNA LVA, 1755-4-26, 19. 1p.

108 Tūrisma padomes štatu saraksts [krievu val.], 25.11.1968. Ibidem, 1755-4-50, 14. lp.

${ }^{109}$ Pavēle Nr. 24 [krievu val.], 06.06.1961., Rìga. Ibidem, 1755-1-10, 28. lp.

${ }_{110}$ Pavēle Nr. 26 [krievu val.], 27.06.1961., Rīga. Ibidem, 30. lp.

${ }^{111}$ Pavēle Nr. 35 [krievu val.], 12.08.1961., Rīga. Ibidem, 39. lp; Pavēle Nr. 41 [krievu val.], 23.09.1961., Rīga. Ibidem, 45. lp.

${ }^{112}$ Rīkojums Nr. 193 [krievu val.], 06.09.1967., Rīga. Ibidem, 1755-1-41, 214. lp.; Rīkojums Nr. 8 [krievu val.], 11.01.1968., Rìga. Ibidem, 1755-1-45, 8. lp.

${ }^{113}$ Protokols Nr. 4 [krievu val.], 31.08.1965., Rìga. Ibidem, 1755-1-31, 7. lp.

114 Protokols Nr. 21 [krievu val.], 11.09.1964., Rīga. Ibidem, 1755-1-22, 36. lp.

${ }^{115}$ Ibidem, 51. lp.

${ }^{116}$ Ibidem, 41. lp.

117 Ibidem, 44. lp.

${ }^{118}$ Pamatrādītāji [krievu val.], 05.01.1962., Maskava. Ibidem, 1755-4-32, 5. lp.

${ }^{119}$ Latvijas tūrisma maršruti. In: Komunisma Rīts, 17.01.1970., 4. lpp.

${ }^{120}$ Protokols Nr. 6 [krievu val.], 29.11.1965., Rìga. LNA LVA, 1755-1-31, 86. lp.

${ }^{121}$ Ibidem, 131. lp.

${ }^{122}$ Ibidem, 93. lp.

${ }^{123}$ Pavēle Nr. 17 [krievu val.], 15.02.1967., Rīga. Ibidem, 1755-1-41, 18. lp.

${ }^{124}$ Protokols Nr. 6 [krievu val.], 29.11.1965., Rïga. Ibidem, 1755-1-31, 76. lp.

${ }^{125}$ Stenogramma [krievu val.], 25.04.1968., Rīga. Ibidem, 1755-1-42, 14. lp.

${ }^{126}$ Ibidem, 19. lp.

${ }^{127}$ Daugavas tūristu kluba vēstule LRTP [krievu val.], 1969, Daugavpils. Ibidem, 1755-1-47, 106. lp.

${ }^{128}$ Stenogramma [krievu val.], 25.04.1968., Rīga. Ibidem, 1755-1-42, 22. lp.

${ }^{129}$ Ibidem, 20. lp.

${ }^{130}$ SCHLESINGer, Marxist Theory and the New Program of the Soviet Communist Party, p. 129.

${ }^{131}$ ILZE VAIVOdE. Alpīnisma attīstība Latvijas PSR 1960.-1991. g. Rīga 2018, 36. lpp.

${ }^{132}$ MARIIA SoKolova. Istoriia turizma: ucheb. posobie. Moskva 2002, s. 352.

${ }^{133}$ ZABLOVSKIS, ZARIN̦A, No Olinkalna līdz Everestam, 80. lpp.

${ }^{134}$ Darba plāns [krievu val.], 1969. LNA LVA, 1755-4-50, 7. lp.

135 Ibidem, 19. lp.

${ }^{136}$ Tūrisma padomes štatu saraksts [krievu val.], 25.11.1968. Ibidem, 14. lp.

137 Pamatrādìtāji [krievu val.], 10.12.1960. Ibidem, 1755-4-29, 8. lp.

${ }^{138}$ Pamatrādītāji [krievu val.], 25.11.1968. Ibidem, 1755-4-50, 21. lp.

${ }^{139}$ Protokols Nr. 6 [krievu val.]., 29.11.1965., Rīga. Ibidem, 1755-1-31, 77. lp.

${ }^{140}$ Republikāniskās tūrisma tautas universitātes mācību programma, 1966, Rīga. Ibidem, 1755-1-36, 145. lp.

\section{SUMMARY}

The definition and aims of Soviet tourism were formulated before WW2, however, until the 1960s the attempts to establish a centralised tourism organisation were unsuccessful. A reorganisation was needed for political and practical reasons. The renewed Program of the Communist Party of the USSR (CP) was established; therefore tourism became a way 
of channelling the theory of the Program into reality. Furthermore, tourism was organised by many small organisations that lacked funding and unity.

Administration of Tourism and Excursions of Latvia (ATEL) started moving towards the centralisation of tourism and other tasks in the 1960s. After the adoption of the new CP's Program, a new wave of ideologization began. It determined the aims and ideological emphasis of ATEL's work, because tourism in the USSR was used for the promotion of the Soviet identity and united collective memory. Tourism had to become a part of people's everyday life - an active way of spending leisure time, accessible to everyone and intended to toughen the Soviet society physically and mentally.

The rapid growth of the number of tourists created a safety problem because of the lack of experience. To solve this problem, ATEL focused on the improvement of the qualifications of its employees and tourists. Training, recruitment of medical staff, safety briefings, and grade limitations became a norm, and it can be evaluated as a positive thing.

The most meaningful reorganisation of Soviet tourism since the 1930s took place in 1962. The Republican Tourism Council of Latvia (RTCL) was more successful in the centralisation of work related to tourism, because a part of the other organisations was closed down to avoid duplication of work. In the 1960s, this organisation expanded significantly. The number of employees of the council almost tripled (from 6 to 17), but the total number of activists was even larger - they worked in RTCL's departments, tourist centres, excursion offices. The departments consisted of 5 sections and 5 commissions that participated in route development, designed the tourism infrastructure, promoted tourism, organised new forms of tourism (for example, automobile tourism), and mass events. However, they faced many difficulties because of the lack of funding and due to negligence or lack of enthusiasm.

The number of tourist centres and their employees increased, while many plans and projects were not carried out.

The RTCL was quite successful in addressing qualification issues that resulted in a new study programme that improved the number of educated tour guides.

The attempts of improvement of tourist's qualifications are hard to evaluate. The organisation tried to improve theoretical and practical knowledge with the implementation of the system of tourism badges. There was some logic in this, however, in reality it did not always help due to the uncontrollable parts of nature and human reaction.

In some fields, the management of tourism was still divided, especially in children and youth tourism. The RTCL was working with the Committee on Physical Culture and Sport of the Council of Ministers, and it did not hinder the efficiency of work like it did in the 1950s. It improved and helped to develop another kind of tourism - tourism as a type of sport. The RTCL was more focused on the organisation of mass tourism, working within the lines of the Central Tourism Council (CTC). Without cooperation with other organisations, tourism would not expand outside the requirements of the CTC.

Overall, RTCL strictly followed the principles of the CTC. That did not always positively influence their work. In the tourist meetings, many tourists expressed criticism and suggestions to the RTCL, but they were not even acknowledged if they did not represent any of CTC's claims. 